\title{
PELATIHAN KEWIRAUSAHAAN STRATEGI PENGEMBANGAN BISNIS DAN IMPLEMENTASI EXCELLENT SERVICE PADA KELOMPOK LASKAR SHOLAWAT KECAMATAN PATRANG JEMBER
}

\author{
Ahmad Sauqi \\ Jurusan Manajemen, STIE Mandala Jember \\ e-mail: sauqi@stie-mandala.ac.id
}

\begin{abstract}
Community service with the theme of business development strategy and implementation of excellent service is carried out at the Laskar Sholawat Commissariat which is located at Jl. Watermelon II No. 2 Patrang District, Jember Regency. There are 16 participants in this entrepreneurship training. Most of the training participants are already entrepreneurs by running small businesses, including in the fields of electronic services, embroidery, cakes, handicrafts, snack traders, livestock, plantations and online shops. Referring to the partner's problems, the servant will provide training on strategies to create customer satisfaction with the concept of excellent service. building a business strategy from 4 basic management foundations, including financial management (don't mix business financial management and family financial management), operational management (how to build service quality or product quality), HR management (how to build a strong personality in entrepreneurship) and marketing management (how to respond to existing opportunities and always update with all market developments) and Marketing strategy training with marketing implementation through E-Commerce.

Keywords: Strategy; Business; Implementation; Excellent; Services.
\end{abstract}

\section{PENDAHULUAN}

Melaksanakan Tri Dharma perguruan tinggi merupakan suatu kewajiban bagi seluruh dosen di Negara Indonesia tercinta ini. Salah satu kewajiban dosen dalam Tri Dharma tersebut adalah pengabdian kepada masyarakat, pengabdian kepada masyarakat sendiri memiliki tujuan untuk memberikan kontribusi nyata bagi bangsa Indonesia, khususnya dalam mengembangkan kesejahteraan dan kemajuan bangsa Indonesia.

Harapan dari pelaksanaan pengabdian masyarakat ini tentunya mengarah pada tercapainya kesejahteraan masyarakat dan kemajuan dari masyarakat yang mengikuti kegiatan dalam pengabdian tersebut. Sebelum melaksanakan pengabdian sudah seyogyanya seorang dosen yang akan melakukan pengabdian 
telah memahami hal apa yang perlu di kembangkan dalam masyarakat tersebut. Dimisalkan permasalahannya adalah di bidang pengembangan ekonomi maka dosen pelaksana pengabdian juga harus lebih jeli apakah permasalahannya sebatas pengembangan atau perlu membangun.

Pengabdian masyarakat yang kami laksanakan selama satu bulan ini, tepatnya dimulai pada pertengahan Juni 2021 dan selesai pada pertengahan Juli 2021 ini lebih mengarah kepada pengembangan ekonomi masyarakat, dimana persertanya adalah para masyarakat yang memiliki usaha kecil dan perlu untuk diberikan stimulus. Stimulus di sini lebih mengarah kepada pengembangan ide kreatif untuk membangun strategi bisnis yang sudah berjalan dengan menerapkan excellent service atau layanan prima.

Peserta dalam kegiatan pengabdian masyarakat ini tergabung dalam kelompok Laskar Sholawat. Laskar Sholawat sendiri merupakan ormas sosial, keagamaan dan pendampingan ekonomi kerakyatan yang di dirikan oleh Mohammad Fawait salah satu politisi yang berada di Kabupaten Jember. Laskar Sholawat melalui Balai Latihan Kerja Industri Jember (BLKI) mengadakan pelatihan kewirausahaan, 3 dosen dari STIE Mandala ditugaskan untuk mengisi pelatihan tersebut, bagi kami kegiatan ini merupakan pengabdian masyarakat. STIE Mandala dengan BLKI Jember telah menjalin kerjasama sejak tahun 2013 dimana untuk instruktur kewirausahaan, administrasi perkantoran dan akuntansi yang mengisi kegiatan pelatihan tersebut adalah dosen dari STIE Mandala.

Pengabdian masyarakat dengan tema strategi pengembangan bisnis dan implementasi excellent service dilaksanakan di Komisariat Laskar Sholawat yang beralamatkan di Jl. Semangka II No. 2 Kecamatan Patrang Kabupaten Jember. Peserta dalam pelatihan kewirausahaan ini berjumlah 16 orang. Para peserta pelatihan rata-rata sudah berwirausaha dengan menjalankan usaha antara lain di bidang servis elektronik, bordir, kue, kerajinan tangan, pedagang camilan, peternakan, perkebunan dan online shop. Berdasarkan informasi dari Bapak Fuad ketua ranting Laskar Sholawat yang berada di Patrang, para peserta adalah pelaku usaha yang saat ini sedang mempertahankan usahanya pada era pandemi covid19 ini agar tetap berjalan dan berkembang meskipun banyak masalah terjadi khususnya dari segi penjualan.

Berdasarkan fakta dilapang setelah kami melakukan pengabdian masyarakat dengan memberikan pelatihan kewirausahaan kepada kelompok Laskar Sholawat di Patrang Jember ini, pada hari pertama pelaksanaan kegiatan mereka banyak yang mengeluhkan merosotnya penjualan baik dari hasil bordir, kue, kerajinan tangan berupa tempat tissue,hasil peternakan berupa ayam kampung dan hasil pertanian berupa buah-buahan dan lain sebagainya. Mereka menyatakan semenjak pandemi covid-19 terjadi penjualan mereka merosot 
hingga 65\% di bandingkan sebelum pandemi. Menurut Moekijat (2011) penjualan adalah suatu kegiatan yang bertujuan untuk mencari pembeli, mempengaruhi serta memberikan petunjuk agar pembeli dapat menyesuaikan kebutuhannya dengan produksi yang ditawarkan serta mengadakan perjanjian mengenai harga yang menguntungkan untuk kedua belah pihak. Berasarkan pemaknaan dari parkar mengenai penjualan maka tentu sudah seyogyanya pedagang harus mampu mendapatkan calon-calon pembeli baru.

Usaha yang telah dimiliki oleh anggota Laskar Sholawat di Patrang ini cenderung stagnan atau tidak berkembang dari waktu ke waktu. Hal ini diungkapkan oleh beberapa pelaku usaha tersebut bahwasanya kegiatan usaha mereka dari awal di rintis sampai dengan tahun 2021 ini masih belum bisa berkembang secara signifikan. Ketidak berkembangan ini mereka ukur dengan semakin merosotnya penjualan, merosotnya pedapatan, serta semakin melemahnya modal yang dimiliki. Berbicara usaha tentu perlu pengembangan agar usaha tetap eksis keberadaanya, artinya setiap usaha tentu di perlukan strategi untuk pengembangan usaha. Strategi bisnis merupakan strategi mencapai tujuan yang sering dianalogikan dengan strategi catur,dimana sistematika berfikir, penyusunan rencana,kesigapan melangkah,keberanian mengambil resiko dan gairah untuk memenangkan pertandingan merupakan beberapan karaktristik permainan catur yang relevan dengan praktek pengelolaan bisnis (Jaewono: 2012).

Konsep membagun kualias layanan yang baik menuju kepuasan pelanggan dan berakhir dengan loyalitas pelanggan masih belum dipahami oleh peserta pelatihan kewirausahaan ini. Kualitas jasa harus dimulai dari kebutuhan pelanggan dan berakhir dengan kepuasan pelanggan serta persepsi positif terhadap kualitas jasa. Kotler ( 2000 ) dalam Fandy Tjiptono ( 2011 : 180 ). Jika ingin bertahan dan sukses, organisasi jasa harus memberikan hasil yang memuaskan yang cocok dengan yang diinginkan konsumen / pelanggan ( Boyd,Walker \& Larreche ; 2000 : 287 ). Oliver dalam Kotler ( 2009 : 138 ) mendefinisikan loyalitas sebagai suatu komitmen yang dipegang secara mendalam untuk membeli atau mendukung kembali produk atau jasa yang disukai di masa mendatang meski pengaruh situasi dan usaha pemasaran berpotensi menyebabkan pelanggan beralih. Dari beberapa terori ini sudah jelas bahwasanya kualitas layanan itu penting, jadi bagaimanapun pelayanan prima harus dilakukan demi berkembang dan berkesinambungannya sebuah usaha.

Berdasarkan analisis situasi yang telah di paparkan sebelumnya dapat kami sepakati bersama dengan Ketua Ranting Laskar Sholawat Kecamatan Patrang Jember dan pelaku usaha kecil sekaligus anggota Laskar Sholawat tersebut terkait penentuan masalah utama yang dihadapi. Adapun permasalahan utama tersebut 
meliputi:

1. Pelaku usaha yang tergabung dalam kelompok Laskar Sholawat mengalami penurunan penjualan sehingga mereka mengalami banyak kerugian khususnya pelaku usaha di bidang servis elektronik, bordir, kue, kerajinan tangan, pedagang camilan, peternakan, perkebunan dan online shop.

2. Pemahaman pelaku usaha terkait strategi pengembangan bisnis masih kurang sehingga usaha cenderung stagnan bahkan merosot dengan bukti modal yang semakin berkurang.

3. Pelaku usaha cenderung kurang memperhatikan kualitas layanan dan belum memahami pentingnya pelayanan prima untuk membangaun kepuasan pelanggan menuju loyalitas pelanggan.

Adapuan ringkasan permasalahan dari pelaku usaha kecil yang tergabung dalam kelompok Laskar Sholawat Kecamatan Patrang Jember adalah pelaku usaha yang tergabung dalam kelompok Laskar Sholawat mengalami penurunan penjualan sehingga mereka mengalami banyak kerugian khususnya pelaku usaha di bidang servis elektronik, bordir, kue, kerajinan tangan, pedagang camilan, peternakan, perkebunan dan online shop. Pemahaman pelaku usaha terkait strategi pengembangan bisnis masih kurang sehingga usaha cenderung stagnan bahkan merosot dengan bukti modal yang semakin berkurang. Pelaku usaha cenderung kurang memperhatikan kualitas layanan dan belum memahami pentingnya pelayanan prima untuk membangaun kepuasan pelanggan menuju loyalitas pelanggan. Berdarakan permasalahan ini kami dari pihak pengabdi ( Dosen STIE Mandala ) melalui penugasan dari STIE Mandala akan memberikan pelatihan kewirauahaan secara ringkas padat dan jelas sehingga para pelaku usaha dalam kelompok ini dapat segera memahaminya secara cepat meskipun hanya dalam kurun waktu 1 bulan. Pelatihan yang secara efektifnya kami lakukan secara offline dengan tetap mengikuti protokol kesehatan sesuai anjuran permerintah dan penyuluhan online melalui media google meet.

Ketiga permasalahan tersebut Insya Allah bisa diselesaikan satu persatu dan untuk itu yang utama kami akan mengadakan pelatihan kewirausahaan dengan tema strategi pengembangan bisnis dan implementasi excellent service ( kelompok laskar sholawat kecamatan patrang jember ). Secara garis besarnya dengan pelayanan prima dan strategi bisnis yang tepat akan mendukung peningkatan penjualan produk ataupun jasa.

Berdasarkan pada poin analisis situasi dan permasalahan mitra maka pengabdi dapat mengusulkan solusi kepada pelaku usaha yang tergabung dalam kelompok Laskar Sholawat Kecamatan Patrang Kabupaten Jember sebagai berikut: 
1. Pelatihan strategi menciptakan kepuasan pada pelanggan dengan konsep excellent service.

2. Pelatihan membangun srategi bisnis dari 4 pondasi dasar manajemen, meliputi manajemen keuangan (jangan mencampur manajemen keuangan usaha dan manajemen keuangan keluarga), manajemen operasional(bagaimana memabangun kualitas layanan ataupu kualitas produk), manajemen SDM(bagaimana membangun pribadi yang tangguh dalam berwirausaha) dan manajemen pemasaran(bagaimana merespon peluang yang ada serta selalu update dengan segala perkembanan pasar).

3. Pelatihan strategi pemasaran dengan pelaksanaan pemasaran melalui E-Commerce.

Berdasarkan 3 solusi yang ditawarkan tersebut dapat kami rangkum pelatihan ini dengan tema strategi pengembangan bisnis dan implementasi excellent service ( kelompok laskar sholawat kecamatan patrang jember ).

Rencana target capaian luaran dari solusi yang ditawarkan kepada pelaku usaha kecil kelompok Laskar Sholawat dapat dilihat pada tabel 1 sebagai berikut ini.

Tabel 1 Rencana Target Capaian

\begin{tabular}{|c|l|c|}
\hline No & \multicolumn{1}{|c|}{ Jenis } & Indikator \\
\hline \multicolumn{2}{|l|}{ Luaran Wajib } \\
\hline 1 & Publikasi ilmiah pada Jurnal ber ISSN/Prosiding jurnal & Ya \\
\hline 2 & Publikasi pada media masa cetak/online/repocitory PT) 6 & Ya \\
\hline 3 & $\begin{array}{l}\text { Peningkatan daya saing (peningkatan kualitas, kuantitas, } \\
\text { serta nilai tambah barang, jasa, diversifikasi produk, atau }\end{array}$ & Ya \\
\hline 4 & $\begin{array}{l}\text { Peningkatan penerapan iptek di masyarakat } \\
\text { (mekanisasi, IT, dan manajemen) }\end{array}$ & Ya \\
\hline 5 & $\begin{array}{l}\text { Perbaikan tata nilai masyarakat (seni budaya, sosial, politik, } \\
\text { keamanan, ketentraman, pendidikan, kesehatan) } 2)\end{array}$ & Tidak \\
\hline Luaran Tambahan & Tidak \\
\hline 1 & Publikasi di jurnal internasional & Tidak \\
\hline 2 & Jasa; rekayasa sosial, metode atau sistem, produk/barang & Tidak \\
\hline 3 & Inovasi baru TT'G & Tidak \\
\hline 4 & $\begin{array}{l}\text { Hak kekayaan intelektual (Paten, Paten sederhana, Hak Cipta, } \\
\text { Merek } \\
\text { dagang, Rahasia dagang, Desain Produk Industri, }\end{array}$ & Tidak \\
\hline 5 & Buku ber ISBN & \\
\hline
\end{tabular}




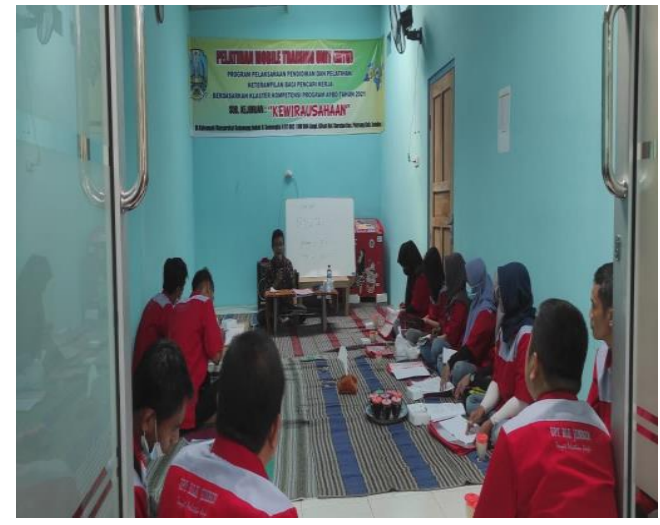

Gambar 1. Kegiatan Pelatihan service

Sumber : Penulis, 2021

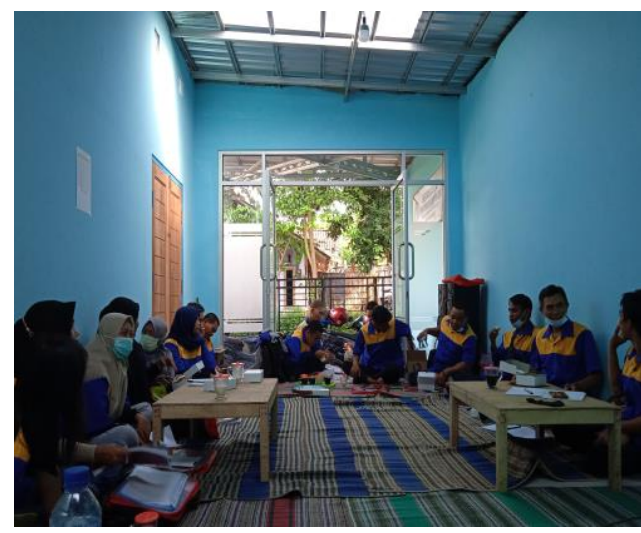

Gambar 2. Diskusi excellent

Sumber : Penulis, 2021

\section{METODE}

Penawaran solusi untuk pelaku usaha kecil kelompok laskar sholawat akan dilakukan dengan cara : Memberdayakan pelaku usaha terkategori UMKM pada kelompok Laskar Sholawat Kecamatan Patran Kabupaten Jember dengan memberikan pelatihan mengenai strategi menciptakan kepuasan pada pelanggan dengan konsep excellent service. Memberdayakan pelaku usaha terkategori UMKM pada kelompok Laskar Sholawat Kecamatan Patran Kabupaten Jember dengan memberikan pelatihan mengenai srategi bisnis dari 4 pondasi dasar manajemen, meliputi manajemen keuangan (jangan mencampur manajemen keuangan usaha dan manajemen keuangan keluarga), manajemen operasional(bagaimana memabangun kualitas layanan ataupu kualitas produk), manajemen SDM(bagaimana membangun pribadi yang tangguh dalam berwirausaha) dan manajemen pemasaran(bagaimana merespon peluang yang ada serta selalu update dengan segala perkembanan pasar). Memberdayakan pelaku usaha terkategori UMKM pada kelompok Laskar Sholawat Kecamatan Patran Kabupaten Jember dengan memberikan pelatihan mengenai strategi pemasaran dengan pelaksanaan pemasaran melalui E-Commerce. 
Metode pendekatan yang ditawarkan untuk menyelesaikan permasalahan pelaku usaha kecil kelompok Laskar Sholawat di Kecamatan Patrang Jember adalah dengan Pelatihan-pelatihan dalam bentuk forum diskusi baik onffline atau online melalui google meet. Pendampingan dengan menggunakan metode learning by doing sebagai tindak lanjut pembekalan yang telah dilakukan.

Partisipasi mitra dalam pelaksanaan program pengabdian masyarakat meliputi. Pelaku usaha kecil kelompok Laskar Sholawat Kecamatan Patrang berperan aktif menghadiri kegiatan pelatihan. Pelaku usaha kecil kelompok Laskar Sholawat Kecamatan Patrang bersedia menyempatkan waktu untuk mengikuti pelatihan dan pendampingan sesuai dengan jenis pelatihan yang sudah di sebutkan sebelumnya,antar lain :

a. Pelatihan strategi menciptakan kepuasan pada pelanggan dengan konsep excellent service.

b. Pelatihan membangun srategi bisnis dari 4 pondasi dasar manajemen, meliputi manajemen keuangan (jangan mencampur manajemen keuangan usaha dan manajemen keuangan keluarga), manajemen operasional(bagaimana memabangun kualitas layanan ataupu kualitas produk), manajemen SDM(bagaimana membangun pribadi yang tangguh dalam berwirausaha) dan manajemen pemasaran(bagaimana merespon peluang yang ada serta selalu update dengan segala perkembanan pasar).

c. Pelatihan strategi pemasaran dengan pelaksanaan pemasaran melalui E-Commerce.

Evaluasi pelaksanaan program dan keberlanjutan program di lapangan setelah kegiatan pengabdian selesai dilaksanakan dengan cara melakukan penilaian kesuksesan dari program pengabdian terhadap pelaku usaha kecil kelompok Laskar Sholawat sangat perlu dilakukan agar tujuan utama dari adanya program ini benar-benar berhasil yakni meningkatnya perekonomian masyarakat serta berkembangnya usaha mikro dari masyarakat itu sendiri. Evaluasi dari pelaksanaan program pengabdian ini adalah Mengukur kesuksesan pelaku usaha kecil kelompok Laskar Sholawat menjalankan strategi pengembangan bisnis dengan pemasaran berbasis E-Commerce serta selalu menjunjung tinggi pelayanan prima sehingga dapat meningkatkan penjualan dan dapat mendapatkan pelanggan baru atau pembeli baru.Keberlanjutan dari pelaksanaan program pengabdian ini adalah kami selaku pengabdi akan berkunjung untuk melihat kondisi pelaku usaha kecil kelompok Laskar Sholawat setelah mendapatkan pelatihan. 


\section{HASIL DAN PEMBAHASAN}

Berdasarkan informasi yang kami dapatkan dari ketua ranting Laskar Sholawat Kecamatan Patrang Jember yakni Bapak. Fuad, pelaku usaha kecil di sana setelah adanya kegiatan pelatihan yang kami lakukan mereka sedikit banyak sudah merasakan manfaatnya, adapun manfaatnya antara lain yang mereka nyatakan adalah sebagai berikut :

1. Ternyata dengan tidak mencampur manajemen keuangan usaha dan manajemen keuangan keluarga membuat tidak kebingunan terkait modal, modal usaha selalu siap.

2. Pelayanan prima memang membuat pelanggan puas dan ternyata memang terbukti mereka mereferensikannya kepada orang lain.

3. Pelaku usaha kecil kelompok Laskar Sholawat menyatakan bahwa pemasaran produk hasil produksi mereka sudah cukup laku keras dibandingkan sebelum adanya penyuluhan, mereka merasa menjual secara online itu menyenangkan dan pembelinyapun bisa dari daerah luar kota.

4. Pelaku usaha kecil kelompok Laskar Sholawat menyatakan bahwa pelanggan sudah mulai banyak hal ini mereka rasakan dengan adanya pemesanan yang semakin banyak di setiap mingggunya.

5. Pelaku usaha kecil kelompok Laskar Sholawat menyatakan bahwa memasarkan produk melalui E-Commerce ternyata mudah kalau di perlajari tingggal posting di group jual beli facebook, taruh di market place facebook atau di jual melalui shopee ataupun tokopedia.

Adapun pencapaian dari kegiatan pangabdian ini meliputi: Pelaku usaha kecil kelompok Laskar Sholawat sudah mampu memanfaatkan Teknologi Informasi untuk memasarkan produk hasil produksinya. Pelaku usaha kecil kelompok Laskar Sholawat sudah mampu memahami pentingnya kualitas layanan dan sudah mengiplementasikan layanan dengan prima.

\section{KESIMPULAN}

Adapun kesimpulan dari kegiatan pengabdian dalam bentuk pelatihan kewirausahaan di kelompok Laskar Sholawat Kecamatan Patrang Jember antara lain, peserta pelatihan menyatakan mendapatkan banyak pengetahuan mengenai pentingnya kualitas pelayanan dalan bentuk pelayanan prima. Peserta pelatihan menyatakan ada efek positif atas pelayanan prima tersebut khusunya pelanggan yang mereferensikan kepada temannya. Peserta pelatihan kewirausahaan sudah mulai memahami bahwa sesungguhnya pasar itu luas dan saat ini tidak terikat oleh waktu dan tempat sebab penjualan bisa dilakukan secara online melalui 
berbagai macam marketplace. Wawasan peserta pelatihan mualai semakin terbuka mengenai strategi pengembangan bisnis sudah seharusnya dilakukan dari internal dahulu dengan membedakan antara manajemen keuangan keluarga dan manajemen keuangan usaha. Mereka juga sudah sangat memahami bagaimana menentukan harga jual dari setiap produk atau jasa yang dihasikan karena sudah memahami apa itu BEP, Total Revenue dan Total Cost serta berbagai macam biaya semisal biaya variabel, biaya tetap dan biaya semi variabel. Intinya peserta pelatihan merasakan efek dari transfer keilmuan secara terori yang diarahkan kepada pratkek terkait manajemen keuangan,operasional, SDM dan pemasaran.

\section{DAFTAR PUSTAKA}

Heizer, Jay \& Barry Render. 2009. Manajemen Operasi Buku 1. Edisi 9. Salemba Empat. Jakarta.

Kasmir, Jakfar. 2013. Studi Kelayakan Bisnis. Edisi 9. Kencana Prenanada Group. Jakarta.

Kotler, Philip. 2009.Manajemen Pemasaran.Edisi 13 Jilid 2 . Edisi Terjemahan Oleh Bob Sabran. Erlangga. Jakarta.

Tjiptono, Fandy. 2008. Strategi Pemasaran. Edisi 3. Andi Offset. Yogyakarta.

Tjiptono, Fandy.2011. Service, Quality \& Satisfaction. Edisi 3. Andi Offset. Yogyakarta. 